Jelena Nedić, MA

Laboratory for Developmental Psychology, Faculty of Philosophy, University of Belgrade, Serbia

Smiljana Jošić, MA

DOI:10.5937/inovacije1503189N

Institute for Educational Research, Belgrade, Serbia

Aleksandar Baucal, PhD

Department of Psychology, Faculty of Philosophy,

University of Belgrade, Serbia

\title{
The Role of Asymmetrical Interaction in the Assessment of Nonverbal Abilities of Children from the Drop-in Center
}

\begin{abstract}
The aim of this article is to show how a differently organized testing procedure can lead to a better understanding of intellectual capacity in children who live or work in the streets. The study presented in it tried to answer the following questions: 1) Does the achievement of children from the Drop-in center improve significantly on a nonverbal intelligence test when solved together with the experimenter? 2) Which type of scaffolding is most effective for children's task solving - affective-motivational, visual cognitive or verbal cognitive? 3) Which features of the asymmetric interactions enable children to find a solution to the tasks that they previously failed to solve? The sample consisted of 30 children from the Belgrade Drop-in center. Initially, the Kohs block design test was administered independently to children, and if they failed to solve it, the experimenter would provide scaffolding gradually, as listed above. The results showed that the children's achievement was very low when doing the test independently, but improved significantly when solving the tasks in interaction. According to cluster analysis four groups of children were identified which served as basis for the qualitative analysis. The conversational analysis between the children and the experimenter showed what proved to be the most significant difference between the groups, which is the function of affective-motivational help with task solving. It also demonstrated that the affective-motivational aid was a part of every successful interaction, but usually needed to be combined with its cognitive variants. As these results suggest, the standardized testing procedures need to be adapted so as to make sure that the children understand the demands of the tasks and that they are motivated and supported to reach the goal of the interaction. Only then can we obtain more valid information about the cognitive capacities of the children from the Drop-in center.
\end{abstract}

Key words: children from the Drop-in center, Kohs block test, asymmetrical interaction, cognitive assessment, dynamic assessment.

1 jelenanedic@ymail.com 


\section{Introduction}

Cognitive assessment tests are commonly standardized on a population of children that make up the majority and the middle class in a given environment (Tovilović \& Baucal, 2007; Maltby et al., 2007). They consist of a determined number of predefined correct answers and their aim is to gather information about the child's current achievement. Due to these characteristics, such testing procedures result in an unfair stratification based on gender, race, socioeconomic status and cultural differences (Tovilović \& Baucal, 2007). Children coming from minority cultures and disadvantaged communities and children less familiar with the test language are often unacquainted with those predefined answers, since they do not share the experience of the majority-culture children (Tovilović \& Baucal, 2007). Therefore, the adequate assessment of marginalized children's achievement represents a major challenge.

Due to the need for increased validity of cognitive assessments, an alternative method called $d y$ namic assessment was developed. The dynamic assessment measures learning processes directly during the testing procedure instead of doing it indirectly, based on the results of the past learning experiences (Sternberg, 2002; Sternberg, 2005). The main goal of this method is to gather information not only on the current, but also on the child's potential achievement (Haywood \& Lidz, 2007), while its main role is to detect the specific barriers to an individual's effective learning, as well as the ways in which these barriers can be overcome (Tzuriel, 2000; Haywood \& Lidz, 2007).

Dynamic assessment is based on socio-cultural theories and the notion of the zone of proximal development (ZPD) introduced by Vygotsky (1977). The information about the respondent's abilities obtained by standard testing procedures represents the current level of the their achievement, or in other words - what the child can do independently (zone of actual development - ZAD). Dynamic assessment, on the other hand, reveals what the child can achieve with the help of a more competent partner. It therefore involves a more competent partner who encourages the child to solve the tasks he failed to solve independently by suggesting correct strategies. Specifically, the more competent person applies scaffolding - a type of support that allows the child to solve the problem by focusing only on those elements of the task he is able to solve with the skills it already possesses, while the more competent partner controls the components of the task that exceed the child's current abilities (Wood et al., 1976). Thus provided aid enables the child to solve the task by acting within its zone of proximal development ( $\mathrm{Vy}$ gotsky, 1977). Scaffolding can be applied in different ways: by simplifying the task, motivating the child, focusing the child's attention to certain aspects of the task, putting the task in a context more familiar to the child, using language that is understandable to children or by using technical tools to make various activities easier. An example of this type of scaffolding can be providing a tutor that solves the task (Wood et al., 1976), or a tutor focusing the child's attention to the structure of the task while constantly providing feedback on the current performance (Fernandez et al., 2001).

It is considered that dynamic assessment can help overcome the obstacles that arise in a test designed without taking into account the cultural characteristics of the marginalized children's sociocultural context (Tovilović \& Baucal, 2007). These obstacles are being overcome more easily with the help of dynamic assessment since it provides marginalized children with a better understanding of the demands they are facing during the course of cognitive assessment.

Socio-cultural theories suggest that learning and development in children within various domains (cognitive, social, emotional, etc.) are influenced by their socio-cultural environment and the expectations of their community about the roles that its members are supposed to take in the life of that community. Different communities have dif- 
ferent socialization goals and make different cognitive demands on children (Fuller \& Garcia Coll, 2010) which could explain the difference between acquired competencies and word meanings in children from marginalized groups and those in children from the majority of the population.

Studies show that dynamic assessment usually enables marginalized children to improve their achievement significantly by allowing them to solve tasks in asymmetrical interaction (hereinafter: AI). A study by Stenberg and Grigorenko (Sternberg \& Grigorenko, 2002) analyzed test approaches based on the notion of the zone of proximal development and showed that children from culturally and educationally deprived environments improved significantly when solving tasks in AI compared to their achievement when solving tasks independently. Similar data were obtained in a research involving preschoolers with low TIP1 test achievement since they also improved significantly during dynamic assessment (Luković, 2011; Luković et al., 2013). Its analysis showed that the preschoolers involved in the research came from poor families and communities, that they were not enrolled in a preschool program and that their parents did not have the capacity to provide conditions which would meet developmental needs of their children.

A study conducted in Netherlands compared the achievement of children from the majority of the population with that of children coming from ethnic minorities, both belonging to the same age group (7-9 years old). It compared their achievement on a seriation test and their improvement after the dynamic assessment (Resing et al., 2009). The results showed that the children from the majority of the population were more successful when solving the task independently, that both groups improved their achievement as a result of graduated scaffolding, but that the children from ethnic minorities significantly improved their achievement compared to their pre-test one (Resing et al., 2009).
A study conducted in Australia (Chaffey et al., 2003) tried to find a better method of identifying gifted Aboriginal children, since they usually underperformed on standardized tests regardless of their abilities. Aboriginal students were tested with Raven's Progressive Matrices in order to determine whether dynamic assessment was an adequate method of identifying gifted children. On average, the children's pre-test achievement was significantly below the average for their age group. After the dynamic testing however, the children in the experimental group showed significant improvement in solving the tasks compared to the results of their initial attempt, but also to the ones in the control group. The authors concluded that dynamic assessment gave them a more valid insight into the development, the abilities and the giftedness of the Aboriginal children (Chaffey et al., 2003).

As the described studies show, children who come from different cultures or from deprived environments show significantly higher levels of achievement when engaged in cognitive task solving within AI than when solving tasks independently. However, these studies have not explored the content of the interaction and the support necessary for allowing marginalized children to express the potentials that they fail to express independently.

\section{Scope of the study}

The scope of this study was to analyze how a differently organized test situation, or more precisely dynamic assessment, may provide a better understanding of the intellectual capacities in a specific group of marginalized children. It focuses on the children from the Belgrade Drop-in center for children living or working in the streets. In particular, it tried to give an answer to the following questions:

- Does the achievement of children from the Drop-in center improve significantly on a nonverbal intelligence test when solved together with the experimenter? The as- 
sumption that the respondents will improve significantly in cooperation with the experimenter is based on the findings that children from socially disadvantaged backgrounds often have a wide ZPD (Chaffey et al., 2003; Sternberg \& Grigorenko, 2002; Resing et al. 2009; Luković, 2011; Luković et al., 2013).

- What types of scaffolding influences children most effectively when solving the tasks that they fail to solve independently? Given that the findings of a study (Baucal, 2003) focused on children from the majority of the population showed that affectivemotivational scaffolding has proved as sufficient for a significant number of children to solve the tasks that they previously failed to solve within a standard testing procedure, it seemed useful to explore whether the children from the Drop-in center would improve their achievement significantly with the same type of scaffolding.

- Because we do not have any findings about this population it would be interesting to see which features of the asymmetric interaction allows children to find a solution to the tasks that they fail to solve independently?

\section{Method}

\section{Sample}

The sample consisted of 30 children, 16 girls and 14 boys, from 10 to 14 years old $(\mathrm{M}=11.4$, SD $=1.4$ ). All of the children used the services of the Belgrade Drop-in center for children who live and/ or work in the streets. They lived in informal settlements, came from large families affected by extreme poverty and declared themselves as members of the Roma community. The children's families supported themselves by collecting secondary raw materials, by working in the flea market, or by work- ing part-time physical labor jobs. All of the children participating in the study worked on the streets (occasionally or regularly), or had done so until recently. Their activities consisted of helping their families in the above mentioned activities or begging. These children were exposed to many risks and to specific challenges that encouraged them to develop different competencies from the ones "typical" for a child of their age. Most of them suffered from educational deprivation to some extent.

The participants were diverse in terms of educational status - two girls completed an adult education program and a total of thirteen children went to school regularly at the time. Out of those thirteen only seven were enrolled in a regular elementary school, while the rest of them were enrolled in schools for adult education. The remaining fifteen children did not attend school at all, or attended it irregularly and ten out of these fifteen have not completed the first grade at the time.

\section{Instrument}

The instrument used for measuring children's intellectual capacities was the Kohs block design test - a subtest from the Revised Wechsler Intelligence Scale for Children (Biro, 1987). This instrument has been chosen because it is a non-verbal test and it is therefore assumed to be less influenced by the children's specific socio-cultural experiences (a "culture free" test -Aptekar 1989, Biro et al., 2006). It was important to administer precisely such a test considering that the population of children we chose as our sample and the ones from the majority of the population differed in mother tongue and in cultural background.

The Kohs block design test requires that the respondents replicate patterns displayed on two-dimensional models by using different colour blocks. It consists of four demonstrations and eight tasks. The first five tasks are solved with four blocks, and the last three with nine blocks. The tasks are arranged by complexity, from simpler to the more 
complex ones and the original procedure requires a limited time frame for completion of each task.

\section{Procedure}

Based on the findings of the pilot study and for the purpose of this study the following changes were made in the testing procedure of the Kohs block design test:

- The testing began with the first demonstration, regardless of the participants' age, so as to enable them to familiarize themselves with the test, understand the task solving principles and gain confidence by solving easier examples.

- Considering that the children manifested signs of distress when facing the time limitation for task completion, it was removed from the procedure. The experimenter would display the next task when it became apparent that the child has applied all the strategies that it could think of, without producing the required result.

During the testing procedure the evaluation of the child's responses was done instantly by the experimenter, and if the child failed to solve two consecutive tasks, the experimenter would stop the standard testing procedure and display the unsolved tasks again but this time providing scaffolding to the child. The affective-motivational scaffolding would be provided first - the experimenter would ask the child to think again about the possible solution and encourage it by expressing confidence in its abilities to succeed. If this kind of scaffolding did not help the child solve the task, the experimenter would move on to the first step of the cognitive scaffolding. This time the child would be presented with the same pattern to be replicated, but with borders of the blocks drawn on the pattern. If this kind of scaffolding did not help the child either, the experimenter would move on to the second step of the cognitive scaffolding which consisted in a verbal explanation of the strategy that was previously suggested visu- ally. The experimenter would then provide a higher level of scaffolding for each task if it became apparent that the child has applied all the strategies that it could think of using the available scaffolding, and still failed to solve the task. After performing the above mentioned intervention, the experimenter would present another task that the child previously failed to solve and provide scaffolding for it as previously described. If the child failed to solve two consecutive tasks despite the scaffolding provided by the experimenter, the procedure would be stopped.

The cognitive scaffolding was provided in a pre-defined manner - the first step (visual aid) was meant to help the child understand that the pattern should be broken down into units (blocks) and then reconstructed by manipulating those units so that they replicate the pattern. The second step (verbal aid) had the task of suggesting the same strategy, only verbally.

With the children's permission and their parents' consent the testing procedure was recorded with a video camera and it lasted around 19 minutes on average. Subjects solved most of the tasks within the time limitations given in the test guidelines. An interesting finding however, is the significant difference in the time it took for the same respondents to solve different tasks, regardless of their difficulty. A possible explanation might be found in the problems with maintaining attention that some of the children encountered while performing the tasks. The recorded material is transcribed according to the Jefferson system of transcription (Jefferson, 2004) and its symbols are explained in the Appendix 1 .

\section{RESULTS}

\section{Quantitative analysis}

\section{Children's individual baseline achievement}

The average number of individually solved tasks was the following: $\mathrm{M}=0.83, \mathrm{SD}=1.41$ (in the 
value range of $0-8)$. Twenty respondents failed to solve any of the tasks in the test (Graph 1) and none of the participants managed to solve the entire test.

In order to be able to compare the achievement in children from the sample with the average achievement in children from the majority of the population that belong to the same age group, it was necessary to consider the standardized test scores. Average score of our sample was $\mathrm{M}=2.46$; $\mathrm{SD}=2.20$ (in the value range 1-19), while the average achievement of children from the majority of the population is in the range of 8-12 points (Biro, 1987). This data shows that the children in our sample achieved a lower average score than the one in the sample used for the test standardization.

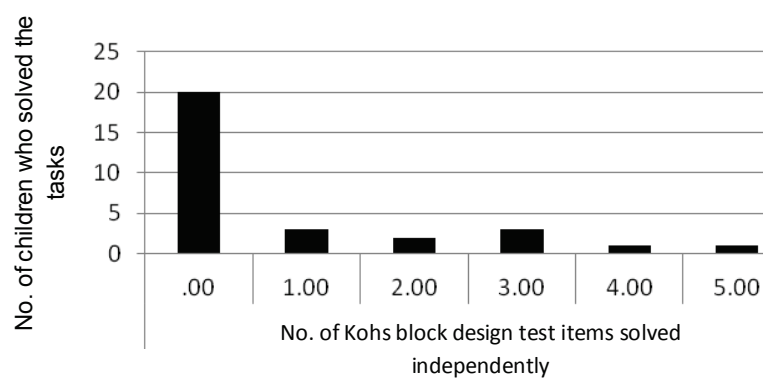

Graph 1 -Distribution of the test scores when children solved tasks independently

\section{Children's achievement with scaffolding}

As we can see from the Table 1, children solved additional 0.53 tasks on average when provided with affective-motivational scaffolding, while they solved one additional task on average with visual type of cognitive scaffolding, and additional 0.96 tasks more on average with the highest level of scaffolding.

The improvement accomplished after each type of scaffolding, that we see in the Table 1, is not statistically significant. Overall however, the children solved about 2.5 additional tasks within the AI (about $31 \%$ of the entire test) after being provided with all types of scaffolding, which is three times higher than their independent achievement and therefore it represents a statistically significant difference $t(29)=-5.73 ; \mathrm{p}=.00$.

After being provided with different types of scaffolding, $20 \%$ of the children in the sample solved the entire test and a total of $77 \%$ of them managed to improve the overall achievement within the AI.

In addition, we wanted to analyze if the respondents' average achievement within AI managed to reach the one in children from the majority of the population. One third of the children from our sample achieved a score of 10.7 points on average, which corresponds to 104 IQ points, while one of the girls even achieved an above-average score of 14 points, an equivalent to 129 IQ points!

\section{Qualitative analysis}

Qualitative analysis of AI was used to explain the ways in which children found solutions to the tasks after being provided with scaffolding. The basis of the qualitative analysis was the hierarchical cluster analysis (Ward's method with squared Euclidean Distance as a measure of distance or similarity was applied) which divided the children into 4 groups based on the similarity of their achievements

Table 1. Achievement of children when solving tasks independently and with different kinds of scaffolding

\begin{tabular}{|c|c|c|c|c|}
\hline & Independent solving & $\begin{array}{c}\text { Affective -motiva- } \\
\text { tional scaffolding }\end{array}$ & $\begin{array}{c}\text { 1st level of cognitive } \\
\text { scaffolding }\end{array}$ & $\begin{array}{c}\text { 2nd level of cognitive } \\
\text { scaffolding }\end{array}$ \\
\hline M of solved tasks & 0.83 & $+0.53(\mathrm{SD}=.89)$ & $+1.00(\mathrm{SD}=1.70)$ & $+0.96(\mathrm{SD}=1.29)$ \\
\hline $\begin{array}{c}\mathrm{M} \text { of solved tasks } \\
\text { independently+scaffolding }\end{array}$ & & 1.36 & 2,36 & 3.32 \\
\hline
\end{tabular}


and improvements within the interaction. Conversation analysis of each cluster helped determine that the groups of children differ in the way they use affective-motivational scaffolding in the interaction with the experimenter.

\section{First cluster - children who improved with all three types of scaffolding}

First cluster consisted of children $(\mathrm{N}=7)$ with a better achievement in solving tasks independently compared to the other groups. They also improved significantly when provided with any of the three types of scaffolding. These are the children with a relatively high ZAD, relatively low abilities that manifest only upon the encouragement and support of a more competent partner (in the form of motivational scaffolding) and a high ZPD, considering the significant improvement they displayed in the interaction.

These children were provided with the motivational scaffolding mostly in order to reduce the insecurity they showed during independent testing. The more competent partner motivated the children to keep working on the solution by confirming to them regularly that they made the right step towards the solution and by reassuring them that they had the ability to master the task.

The section below represents a part of a conversation that took place between the experimenter and a girl named Marijana $\underline{2}$ (14). It illustrates the part where the experimenter is providing the child with the affective-motivational scaffolding and therefore the way in which the children from this group used this type of aid to improve their achievement.

2 The names of all the children mentioned in the study are not real and have been replaced in order to protect the anonymity of the participants.
Excerpt 1

1. Exp.: and now this picture? (1.0) also [with all of these blocks]

$(2.0)$

a sada ova sličica? (1.0) isto od [svih ovih kockica] (2.0)

2. Marijana: [oh:: teacher ] [iju:: : nastavnice]

3. Exp.: $c^{\prime} m o n$ try (2.0) try see how you've solved nicely all of it so far (6.0)

ajde probaj (2.0) pokušaj vidiš kako si sve fino rešila do sada (6.0)

4. Marijana: this is really hard ovo je stvarno teško

5. Exp.: hm? $m$ ?

6. Marijana: this is really hard (1.0)

ovo je stvarno teško (1.0)

7. Exp.: well right $c^{\prime}$ mon try (.) it's not a big deal (1.0) you did all of it $\mathrm{m}$ : arranged them right (.) first six of them (2.0) [you understand all of it well]

pa dobro ajde pokušaj (.) nije to ništa strašno (1.0) sve si se m: lepo složila (.) svih prvih šest ovih (2.0) [sve ti to lepo razumeš]

8. Marijana: [well it's really hard] (4.0) ((arranging blocks))

[pa stvarno teško ] (4.0) ((slaže kocke))

9. Exp.: $\mathrm{mhm}$ mhm

10. Marijana: hm? hm?

11. Exp.: good (.) let's move on? (2.0)

dobro (.) ajmo dalje? (2.0)

12. Marijana: is it like this (2.0) jel ovako (2.0)

13. Exp.: you are looking for this picture (1.0) so you are looking for a way to make it like this (25.0)

tražiš ovu sličicu (1.0) znači gledaš kako da napraviš ovo što je (25.0) 
14. Marijana: ((turns blocks, moves them around, but makes no progress in terms of completing the pattern)) i don't know if it's like this (6.0) ((still turns and moves the blocks around, forms a part of the pattern))

(lokreće kocke, premešta ih, ali ne napreduje u formiranju figure)) ne znam jel tako (6.0) (( $i$ dalje okreće i premešta kocke, formira jedan deo tražene figure))

15. Exp.: $\mathrm{mhm}(6.0)$ $\mathrm{mhm}(6.0)$

16. Marijana: no (23.0) ((takes the blocks one by one and checks every side to see if it fits in the reproduced part of the pattern)) it's not like this (9.0) it's not like this right (1.0)

ne (23.0) (luzima po jednu kocku i isprobava svaku stranicu da li se uklapa u složeni deo figure)l nije ovako (9.0) nije ovo ovako jel tako (1.0)

17. Exp.: here look at the picture and it should look the same (44.0)

evo gledaš na slici pa treba da ti ispadne tako isto (44.0)

18. Marijana: ((takes the blocks one by one and checks which one fits in the reproduced part of the pattern)) ah: : wait no $(3.0)$ i did this good (llooks at the experimenter for confirmation))

(luzima po jednu kocku i isprobava koja stranica se uklapa u složeni deo figure)l ja::o čekaj ne (3.0) ovo sam dobro uradila ((pogledom traži potvrdu od ispitivača))

19. Exp.: $\mathrm{mhm}$ you see it looks the same as in the picture yes

mhm vidiš da je kao i na sličici da 20.Marijana: this is already: (1.0) this angle right (2.0) ha?

ovo je već: (1.0) ovaj ćošak jel tako (2.0) a?
21.Exp.: come on you look (3.0) how it should be done from there on (37.0) hajde gledaš (3.0) kako bi to trebalo dalje (37.0)

22.Marijana: ((apparently without a clear plan, she takes blocks one by one and checks every side to see if it fits into the reproduced part of the pattern)loh man (6.0) i don't know which one goes here $(2.0)$ i don't know [how ]

(lnaizgled bez jasne ideje isprobava različite strane kocaka kako se uklapaju u deo figure koji je složila)) au je (6.0) ne znam šta ide (2.0) ne znam [kako]

23. Exp.: well you started off great there is not much left come $0: n(9.0)$ pa odlično si počela nije ti još puno ostalo a:jde (9.0)

We can see from the Excerpt 1 that the girl was expressing insecurity from the very beginning, arguing that the task was hard (turns 2, 4, 6 and 8) before she even tried to solve it. She attempted to solve the task only after the experimenter expressed his confidence in her ability to master the task by pointing out the fact that she solved all of the previous ones successfully (turn 7). Also, for the most part of the conversation the girl was asking for the experimenter's confirmation about the accuracy of the reproduced part of the pattern, which can be seen in turns $10,12,16,18,20$. The experimenter kept referring her to her own judgment and the comparison between the reproduced pattern and the one on the model (turns 13, 17, 19, 21). In turn 22 Marijana says openly that she doesn't know how to solve the task, but when she receives the necessary positive evaluation of her answer by the experimenter (turn 23), she makes progress in the task completion.

Based on the analysis of the interaction between Marijana and the experimenter, we may conclude that the motivational scaffolding served as a "support system" for the girl throughout the tasks 
solving process - she arrived to the solution step by step, by asking confirmation for her competencies from the experimenter and by checking with him the accuracy of every step in the process.

\section{Second cluster - children who didn't manage to improve with scaffolding}

The second cluster consisted of children ( N =11) with low achievement when solving tasks on their own, that barely improved when provided with any kind of scaffolding. Therefore, these children have a low ZAD, low abilities that may be manifested with the encouragement by a more competent partner (in the form of motivational scaffolding), and also a low ZPD because they did not manage to improve even when provided with the cognitive scaffolding.

These children were provided with motivational scaffolding mostly in order to confirm the accuracy of each step they made towards the solution and maintain their motivation throughout the task solving process. They had difficulty understanding the tasks, the strategies suggested by the experimenter, and the context of the assessment process. Therefore, a confirmation of their answers' accuracy was perhaps the only way for them to check whether they are doing what they were asked by the experimenter.

The Excerpt 2 contains a transcript of the conversation that took place while providing verbal type of cognitive scaffolding to a girl named Katarina (11) for the easiest task in the test. She, like most of the children in this cluster, managed to slightly improve her achievement only with the combination of cognitive and affective-motivational scaffolding.

\section{Excerpt 2}

1. Exp.: so you look at each of those blocks $(1.0)$ and find a side like this one and place it (.) then like this one and place it (.) then like this one and this one and place it? (.) and like this one and place it. ( (points with finger each of the marked sides on the model, and then each block)) (2.0) that's the way you put blocks

znači gledaš svaku ovu (1.0) i nađeš takvu stranicu i staviš (.) pa nađeš ovako pa staviš (.) pa ovako pa staviš? (.) i ovako pa staviš. ((svaku obeleženu stranicu na modelu pokazuje prstom pa zatim pokazuje na po jednu kocku)) (2.0) sve tako stavljaš kockice

2. Katarina: (lobserves and turns blocks, joins two together)) like this=

(lposmatra i okreće kocke, spaja dve)) ovako=

3. Exp.: $=\operatorname{mhm}$ good (5.0) $=$ mhm dobro (5.0)

4. Katarina: ((turns one block and puts it in the right place)) like this

(lokreće jednu kocku i stavlja je na pravo mestol) ovako

5. Exp.: ((nodes)) yes great (1.0)

and (2.0) the last one(4.0)

((klima glavom)) jeste odlično (1.0)

i (2.0) ova poslednja (4.0)

6. Katarina: ((turns the last block and puts it in the right place))

(lokreće poslednju kocku i stavlja je na mesto))

7. Exp.: well done kaća (1.0) you see (.) great (.) good?

bravo kaća (1.0) evo vidiš (.) odlično (.) dobro?

The Excerpt 2 shows us that an explanation of the strategy and a visual presentation on the model itself together with a non-verbal explanation of the model's connection to the blocks (turn 1) were the methods that helped the girl understand and apply the presented strategy (turn 2). However, due to the 
fact that Katarina wasn't certain whether she understood the task's requests, she needed a constant confirmation that she was on the right path, and therefore she continued to check the accuracy of every answer with the experimenter (turns 2 and 4 ).

\section{Third cluster - children who improved with cognitive scaffolding}

The third group of children $(\mathrm{N}=3)$ singled out by cluster analysis managed to improve only when provided with the cognitive scaffolding - they had a low initial achievement, did not improve with the motivational scaffolding, but improved significantly with both types of cognitive scaffolding. It seems that this group of children has a low ZAD, low abilities that are manifested when the child is encouraged (in the form of motivational scaffolding) and a high ZPD.

Using conversation analysis, we concluded that the motivational scaffolding in this group focused on maintaining the children's attention and structuring the process of task solving. However, on its own, it was not enough for children to improve their achievement because of their initial wrong approach to the task.

The Excerpt 3 represents a conversation conducted while providing visual type of cognitive scaffolding to Marko (10). It illustrates how the children from this cluster used motivational scaffolding to improve their achievement.

\section{Excerpt 3}

1. Exp.: all right? (1.0) and if we now display (2.0) this picture? (.) instead of this one?= () (moves the card with the pattern and places a card containing the visual type of cognitive scaffolding in front of Marko))

dobro? (1.0) a ako sad damo (2.0) ovu sličicu? (.) umesto ove?= ((sklanja karticu s modelom i stavlja ispred
Marka karticu koja sadrži vizuelnu kognitivnu pomoć))

2. Marko: =no no leave them both =ne ne pusti obadve tu

3. Exp.: ((smiling)) well [ok that ] is the same thing, there is just with one extra thing drawn

((osmehuje se)) pa [dobro to] ti je to isto samo je dodatno ovo nacrtano

4. Marko: [doesn't matter] = [nema veze]=

5. $\operatorname{Exp}$.: =c'mon how would you do it if you had this? (1.0) does it then help you find which blocks you [should]

=ajde pogledaj kako bi to ovde kad imaš ovo? (1.0) da li ti onda pomaže da razmisliš koje kockice tu [treba]

6. Marko:[i know] teacher= [znam ] nastavnice=

7. Exp.: =c'mon try (1.0) =ajjde da probaš (1.0)

8. Marko: ((arranges blocks one by one in an orderly manner)) like this $(3.0)$

((reda jednu po jednu kocku redom)) ovo vako (3.0)

9. Exp.: good? (1.0) and where do these other two go (3.0)

dobro? (1.0) i kako idu ove druge dve (3.0)

10. Marko: ((puts one more block in place))

((stavlja još jednu kocku na pravo mesto))

11. Exp.: like that (.) great? and how will the last one go (3.0)

tako (.) odlično? I poslednja kako će (3.0)

12. Marko: ((puts the last block in place))

((stavlja poslednju kocku na pravo mesto))

13. Exp.: well done you see there are enough blocks (.) mhm? (1.0) 


excellent (1.0) great (1.0) all
right?
bravo eto vidiš da ima (.) mhm?
(1.0) super (1.0) odlično (1.0)
dobro?

The previous passage showed us that the boy did not improve when provided with visual type of cognitive scaffolding because in turn 2 he asked the experimenter to leave both cards on the table - the one with the pattern and the other with borders of the blocks drawn on the pattern. The explanation which the experimenter then provided (turn 3), that the patterns on the cards are the same, and that the second card contains only an additional drawing encouraged the boy to focus on the additional drawing and realize that he needed to think of the pattern as a set of 4 blocks. This kind of conclusion was drawn due to the boy's confirmation in turn 6 that he understood how the task should be approached, and because shortly after he began to look for the appropriate sides of the blocks and reproduced the pattern accurately (turn 8 ). In turn 8 the boy asked for confirmation, and once the examiner had given it to him, he was motivated to continue (turn 9). A similar dynamic continued to play out in subsequent turns $(10,11$ and 12), until Marko made an exact reproduction of the pattern. In turn 13 the experimenter pointed out to the boy that he was indeed given all the necessary blocks to reproduce the pattern because of the boy's previous claim that both blocks were necessary for solving the same task when he was provided with solely motivational scaffolding.

The conversation analysis showed that the motivational scaffolding had a purpose of encouraging a careful observation and analysis of the visually suggested strategy. It also provided the boy with the necessary support to continue working on the solution confirming that he was adequately using the suggested strategy. In addition, this form of scaffolding partially structured the task solving process by motivating Marko to move on to the next step ("Good, and where do these other two go?").

\section{Fourth cluster - children who improved only with the highest level of scaffolding}

Fourth group of children $(\mathrm{N}=9)$ managed to improve their achievement only when provided with the highest level of scaffolding - they had an extremely low initial achievement and significantly improved only with the verbal type of cognitive scaffolding. These children have a very low ZAD, low abilities that are manifested only with encouragement within AI (in the form of motivational scaffolding) and a relatively wide ZPD because most of them significantly improve their achievement when provided with scaffolding compared to their initial attempt of solving the tasks independently.

The motivational scaffolding provided to this group of children was mostly focused on motivating them to continue to work on the solution and on directing their attention to the details, because they had difficulty understanding the goal of the task which was to reproduce the displayed pattern and not just to place blocks next to each other with a particular side facing up.

The Excerpt 4 represents the conversation that took place between the experimenter and Jasna (12) while providing her with the highest level of scaffolding. It illustrates the manner in which the children from this cluster used the motivational scaffolding in interaction with the experimenter.

\section{Excerpt 4}

1. Exp.: $\mathrm{mhm}$ so check carefully if every one of these is placed exactly as you placed them (1.0) each of these sides (.) like the one here, on the blocks (lpoints with a finger to the marked sides of the blocks on the pattern, and then to the blocks in front of the participant)) (18.0)

mhm znači svaka ova lepo proveriš da li je potpuno isto nameštena kao kod tebe (1.0) svaka ova stranica (.) kao jedna ovde na kockicama (lprstom 
pokazuje na obeležene stranice na modelu, pa na ispitanicine kocke)) (18.0)

2. Jasna: here evo

3. Exp.: hm? let's check this one to see if it is [is it ] placed properly ((points on one marked side of the block on the pattern )) hm? ajde da proverimo ova da vidimo kako je ona [jel ona kako] treba nameštena ((pokazuje na jednu obeleženu stranicu na modelu))

4. Jasna:

[here it i:s] (2.0)

[evo je tu: ] (2.0)

5. Exp.: [hm]? [hm]?

6. Jasna: [m:]well it's the same $[\mathrm{m}:] \mathrm{pa}$ ista

7. Exp.: all right, this side? dobro ova stranica?

8. Jasna: here (2.0) ah:: no. ((takes the block whose orientation was wrong and tries to rotate it to find the right orientation))

evo (2.0) a: : ne. ((uzima kocku čija je orijentacija pogrešna i pokušava da je okrene pravilnol)

9. Exp.: aha (.) what should be done here $(2.0)$

aha (.) šta treba da se napravi (2.0)

10. Jasna: like this ((places the block properly)) (1.0)

tako ((stavlja kocku na pravo mesto)) (1.0)

11. Exp.: like tha::t(.) we:ll done (.) you see that it's all good now ta::ko (.) bra:vo (.) vidiš da je sad sve dobro

In the Excerpt 4 we saw that the suggested strategy was made clearer to Jasna by connecting the particular sides marked on the pattern to their appearance on the blocks (turn 1) in order for her to understand the requirements of the task - it wasn't enough to turn the blocks with the right side up, but she also had to rotate them correctly so as to reproduce the right pattern. The experimenter then tried to structure the task solving process (turn 3) by suggesting to Jasna to check each of the marked sides on the pattern against the corresponding sides on the blocks in order for her to notice the difference, and this strategy led to the desired result (turn 8).

The conversation analysis showed that the Jasna's initial understanding of the task was only to some extent correct (because she observed the displayed model as a set of 4 elements), as she did not realize that the purpose of the elements was to create a certain pattern. The motivational scaffolding in this group focused on motivating the children to continue to work on a solution and on directing their attention to details so that they would realize it is necessary to compare the pattern's reproduced part with the one on the model.

\section{Discussion}

The participants have achieved a significantly lower score when solving tasks independently compared to the norms determined through the instrument's standardization within the majority of the population. This finding did not come as a surprise, given that the evaluation of the participants' achievement was done based on standards that are not entirely adequate for them. Considering the experiences specific to the children from the Dropin center, who are living in a different culture and in poverty, it is safe to assume that they have developed competencies relevant to such living conditions (Biro et al., 2006). Therefore, they possess less incentives for developing skills assessed by the test as opposed to the children from the majority of the population. Also, given that the half of the children dropped out of school or attend it irregularly, they are likely to have had fewer opportunities to develop competencies for successful test solving such as problem-solving skills or maintaining focus (Biro et 
al., 2006). The assessed children haven't had the opportunity to develop these skills at home either, because of their unfavorable living conditions.

However, the analysis of the children's achievement after solving tasks within the AI showed different results. They made a significant improvement and achieved on average a result that was three times higher than the one from their first independent attempt. This kind of finding was also expected and in line with the previous studies on the improvement of children from disadvantaged backgrounds within AI (Sternberg \& Grigorenko, 2002; Luković, 2011; Luković et al., 2013; Chaffey et al., 2003). In addition, the quantitative analysis did not single out one type of scaffolding that had the most significant influence on the children's improvement. It showed that only once all types of scaffolding were provided, the improvement was significant. On the other hand, during the qualitative analysis, motivational scaffolding revealed to be an integral part of almost every successful interaction, but usually in combination with cognitive scaffolding. Motivational scaffolding had an important role in problem-solving process in all groups of children, but its role was somewhat different for each group. In other words, these findings suggest that motivational and cognitive aspects of social interaction may have different relations and roles between them. They also highlight the importance of including different combinations of motivational and cognitive scaffolding when working with marginalized children allowing them that way to develop more easily within their own potential.

For some children, the motivational scaffolding had a role in helping them overcome their insecurities and providing them with further support throughout the task solving process. They received a confirmation from the experimenter when they reproduced a part of the pattern correctly and when they chose the right task solving strategy. Additionally, it served as a reminder to children that they should carefully check their answers. The described method was also used in combination with cognitive types of scaffolding. This group of children has not had difficulties understanding the tasks and proposed strategies, and often already had the necessary competencies for solving them, but they were just not manifested when the children tried to solve the tasks independently. This kind of relation between motivational and cognitive scaffolding gave results in children who had the highest educational status in the sample.

However, some children needed a different kind of support. In their case, the motivational scaffolding was mostly focused on verifying the accuracy of the steps made in the task solving process and maintaining their motivation to solve the task. Due to the fact that these children were confused by the task demands, the motivational scaffolding was a way for them to find out if they were headed in the right direction. These were the children with the lowest educational status in the sample, and it seemed that their lack of understanding of the tasks and the task solving principles was due to their lack of experience with similar problems. Since the testing situation represented a relatively unfamiliar situation for them, whose meaning and goal they had difficulty understanding, one of the main objectives of motivational scaffolding with them was maintaining their motivation to continue working on the task's solution.

There were some children that needed help primarily in maintaining attention and structuring the task solving process. In this case, only the visual type of cognitive scaffolding showed as effective. These children also had difficulty understanding the tasks and requirements that were placed on them. However, quickly after being provided with the visual type of cognitive scaffolding they realized the right task solving strategy and applied it. After failing to implement the same strategy in the following tasks based on their previous experience, these children quickly realized that they needed cognitive scaffolding and asked for it while being provided with motivational scaffolding. It is also possible that these children realized that task solving was easier with cognitive scaffolding and therefore were not able to make a greater cognitive ef- 
fort and solve the tasks without it due to their lack of attention and focus. The fact that they lack focus is additionally confirmed by the role that the motivational scaffolding had for them - it was directed towards motivating them to continue the task solving process and turning their focus on the key aspects of the displayed pattern.

Finally, some children required motivational scaffolding in the form of motivation for moving forward towards the solution. They also needed to have their attention drawn to the details and directed towards comparing the reproduced part of the pattern with the displayed model. Once provided with that kind of scaffolding in combination with the verbal type of cognitive scaffolding, they were able to achieve the goal of the interaction. These children also have a low educational status, so it is not surprising that they also had difficulty understanding the assessment situation. However, they had a clear idea of how to group the blocks, the only thing they failed to realize is that the blocks should be grouped into a pattern, not just put together with the right side up. We can therefore assume that this kind of reasoning is also a consequence of the children's lack of experience with similar materials and problems, and that is why they failed to understand the part of the meaning which was "implied" (that the displayed pattern should be reproduced).

\section{Conclusion}

As shown in the results, the children from the Drop-in center achieve low scores in standard testing procedures, regardless of their actual cognitive abilities. Practitioners who work with such marginalized groups of children should bare this in mind and carefully draw conclusions about their abilities when performing this kind of assessment.

Also, our findings have confirmed that children improve their achievement significantly within
AI, but that it is impossible to single out one type of scaffolding that enables them to do so. It is necessary to combine different types of scaffolding in order for children to improve. Although motivational scaffolding proved to be a vital part of all interactions that resulted in success, it usually had to be combined with cognitive types of scaffolding. In addition, children used it in different ways and also different ways of combining motivational and cognitive scaffolding produced results with different children. Therefore, in order to obtain more accurate information about the cognitive capacities of marginalized children, it is necessary to adapt the standardized testing procedures so as to make sure that the children understand the demands of the tasks and that they possess the necessary motivation and support to achieve the goal of the interaction.

These conclusions stress the importance of providing motivational scaffolding to marginalized children during cognitive assessment and teaching. Even when presented with the problem solving strategy, there is a possibility that these children do not reach the goal unless an adjusted kind of motivational scaffolding is included in the presentation. This approach can be applied to the children from the Drop-in center by providing them with the necessary support for developing their cognitive abilities through the work of pedagogical assistants who would be in charge of this task.

A careful analysis of the participants' achievement, improvement and background information led us to the conclusion that the children who attend school regularly and show a greater independent achievement, also show a greater ability for improvement with a more competent partner. However, the question that remains unanswered by this study is what type of scaffolding would enable improvement of the children who rarely have the opportunity to interact with the tasks and materials similar to those in the cognitive assessment tests. 


\section{References}

- Aptekar, L. (1989). Characteristics of the Street Children of Colombia. Child Abuse \& Neglect, 13, 427-437.

- Baucal, A. (2003). Konstrukcija i ko-konsrukcija u zoni narednog razvoja: Da li i Pijaže i Vigotski mogu biti u pravu? Psihologija, 36(4), 517-542.

- Biro, M. (1987). Priručnik za REVISK - Revidirana skala za merenje inteligencije po principima Vekslera. Beograd: Savez društava psihologa Srbije.

- Biro, M., Novović, Z. i Tovilović, S. (2006). Kognitivno funkcionisanje edukativno zapuštene dece predškolskog uzrasta. Psihologija, 39 (2), 183-206

- Chaffey, G.W., Bailey, S.B. \& Vine, K.W. (2003). Identifying High Academic Potential in Australian Aboriginal Children Using Dynamic Testing. Australasian Journal of Gifted Education, 12 (1), 42-55.

- Fernandez, M., Wegerif, R., Mercer, N., Rojas-Drummond, S. (2001). Re-conceptualizing “Scaffolding” and the Zone of Proximal Development in the Context of Symmetrical Collaborative Learning. Journal of Classroom Interaction 36 (2), 40-54.

- Fuller, B \& Garcia Coll, C. (2010). Learning From Latinos: Contexts, Families, and Child Development in Motion. Developmental Psychology, 46(3), 559-565.

- Haywood, C.H. \& Lidz, C.S. (2007). Dynamic Assessment in Practice - Clinical and Educational Applications. New York: Cambridge University Press.

- Howe, C. \& Mercer, N. (2007). Children's Social Development, Peer Interaction and Classroom learning. Cambridge: University of Cambridge Faculty of Education.

- Jefferson, G. (2004). Glossary of transcripts symbols with an introduction. U (Ed. Lerner, G. H.) Conversation Analysis: Studies from the first generation. Amsterdam: John Benjamins Publishing Company.

- Luković, S. (2011). Merenje zone narednog razvoja u predškolskom testiranju: TIP-1 kao instrument za dinamičko procenjivanje. Master rad. Univerzitet u Beogradu, Filozofski fakultet.

- Luković, S., Baucal, A. i Tišma, B. (2013). Dinamičko procenjivanje zone narednog razvoja testom za ispitivanje prvaka-1 (TIP-1). Primenjena psihologija, 6(4), 371-383.

- Maltby, J., Day, L. \& Macaskill, A. (2007). Personality, Individual Differences and Intelligence. Harlow: Prentice Hall.

- Resing, W.C.M., Tunteler, E., de Joung, F.M. \& Bosma, T. (2009). Dynamic testing in indigenous and ethnic minority children. Learning and Individual Differences, 19 (4), 445-450.

- Sternberg, R. J. (2005). The Theory of Successful Intelligence. Interamerican Journal of Psychology, 39 (2), 189-202.

- Sternberg, R. J., Grigorenko, E. L. (2002). Dynamic testing: The Nature and Measurement of Learning Potential. Cambridge: Cambridge University Press.

- Tovilović, S. i Baucal, A. (2007). Procena zrelosti za školu: Kako pristupiti problemima procene zrelosti i adaptacije marginalizovane dece na školu? Beograd: Centar za primenjenu psihologiju Društva psihologa Srbije.

- Tzuriel, D. (2000). Dynamic Assessment of Young Children: Educational and Intervention Perspectives. Educational Psychology Review, 12(4), 385-435.

- Vygotsky, L. S. (1977). Mišljenje i govor. Beograd: Nolit.

- Wood, D., Bruner, J.S. \& Ross, G. (1976). The Role of Tutoring in Problem Solving. Journal of Child Psychology and Psychiatry, 17 (2), 89-100. 


\section{APPENDIX}

\section{Appendix 1 - Symbols used in transcription (Jefferson, 2004)}

[ Marks the start of turn overlap

] Marks where turn overlap ends

$=$ Marks concatenation of two turns

(.) Marks a pause of about $1 / 10$ of a second

(1.0) Marks a pause whose length is marked in seconds

- Marks intonation declining

? Marks intonation increase

$((\boldsymbol{a b c}))$ Marks additional descriptions of the transcriber

_ Marks an accentuated syllable or part of a word

: Marks an extended voice

\section{Appendix 2 - Cluster analysis - dendrogram}

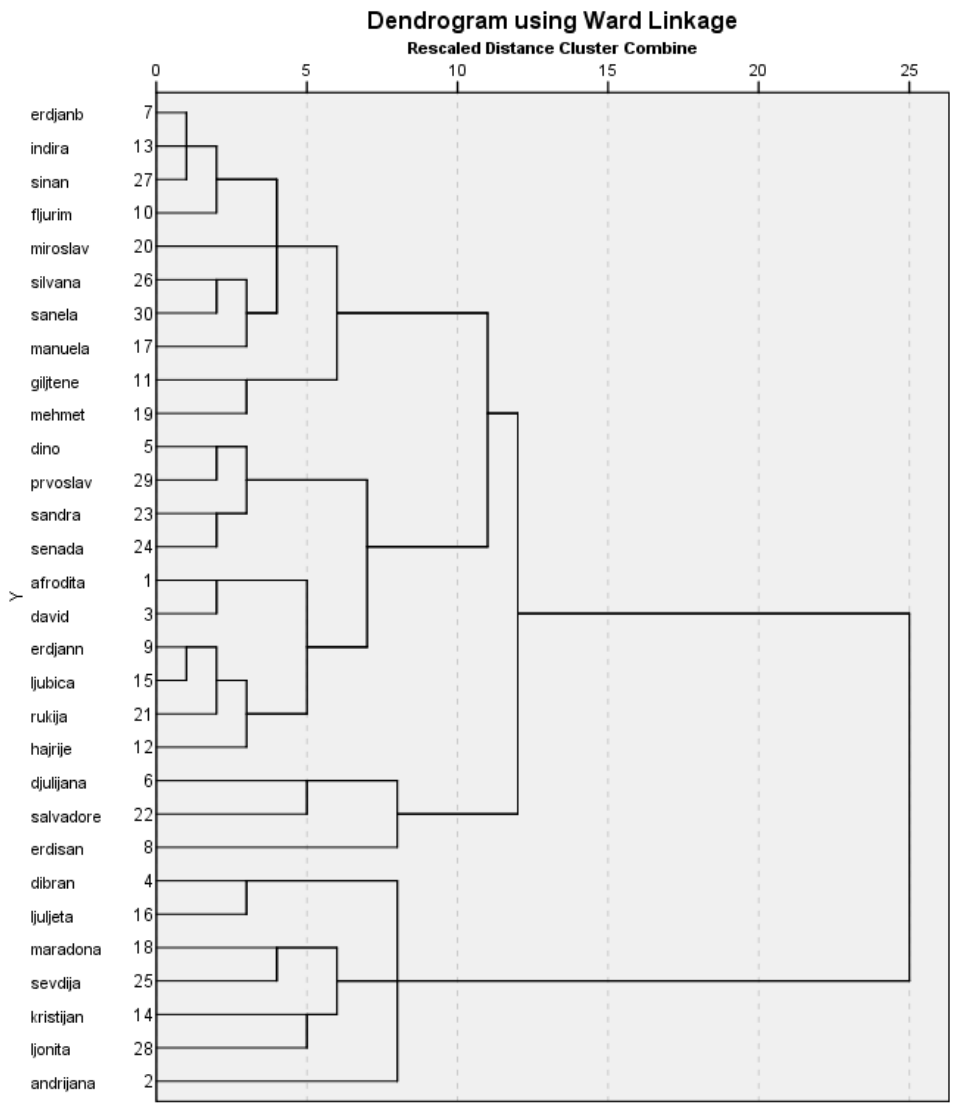




\section{мср. Јелена Недић}

Лабораторија за развојну психологију, Филозофски факултет, Универзитет у Београду, Србија

\section{мср. Смиљана Јошић}

Институт за педагошка истраживања, Београд, Србија

\section{др Александар Бауцал}

Одељење за психологију, Филозофски факултет, Универзитет у Београду, Србија

\section{Улога асиметричне интеракције у процени невербалних способности деце из Свратишта}

Когнитивна процена деце из маргинализованих средина често је отежана због културолошких разлика које се јављају између нормираног и испитиваног узорка, затим због препрека које носи низак социоекономски статус испитиване деце, њихова едукативна депривираност, али и језичких баријера које се јављају приликом тестирања. Управо ради потребе да се повећа информативност когнитивних процена и код деце из маргинализованих средина, развило се динамичко процењивање, које подразумева добијање информација о актуелном, али и о потенцијалном постигнућу детета.

У овом истраживању желели смо да боље разумемо интелектуалне капацитете и специфичности корисника београдског Свратишта за децу која живе или раде на улици. Конкретно, циљ истраживања био је усмерен ка тражењу одговора на следећа питања: 1) Да ли се постигнуће деце из Свратишта на невербалном тесту интелигенције значајно повећава када га решавају у асиметричној интеракцији са испитивачем; 2) Која врста помоћи је најчешће била потребна деци да ураде задатке које нису могли самостално - афективно-мотивациона помоћ, визуелна или вербална варијанта когнитивне помоћи; 3) На који начин су деца у оквиру датих помоћи дошла до решења за која претходно нису имала неопходне когнитивне структуре или нису успела да их употребе да би дошла до решења?

У истраживању је учествовало тридесеторо деце, корисника Свратишта за децу који живе у неформалним насељима, потичу из многочланих, екстремно сиромашних породица и изјашњавају се као припадници ромске заједнице. Највећи број њих одликује васпитно-едукативна депривираност.

Невербалне когнитивне способности деце мерене су тестом Косове коцке - суптестом у РЕВИСК тесту. Задатак сваког детета био је да прво покуша самостално да склопи коцке и тек у случају неуспеха испитивач је пружао прво афективно-мотивациону помоћ - сугерисао је детету да размисли поново и храбрио га тиме да он верује да дете сигурно може да реши тај задатак. Уколико уз овај ниво помоћи дете не би успело да реши задатак, испитивач је прелазио на први корак когнитивног нивоа помоћи (визуелна когнитивна помоћ), у ком се детету давао модел са исцртаним границама коцака. Ако ни уз овај ниво помоћи дете не би успело да реши задатак, испитивач је прелазио на други корак когнитивног нивоа помоћи, који је обухватао вербално представљање стратегије која је претходно визуелно сугерисана. Након овог нивоа помоћи испитивач је прелазио на следећи задатак који дете није успешно решило у самосталном покушају. Сва испитивања су снимана видео-камером, уз претходно одобрење сваког детета и сагласност родитеља. 
Добијени резултати показују да су у оквиру самосталног решавања деца постизала значајно ниже скорове у односу на норме које су настале на основу стандардизације инструмента у општој популацији. Овај налаз је очекиван, с обзиром на то да су постигнућа деце процењивана на основу нормативне групе која није референтна за испитивану популацију. Међутим, испитивана деца су у асиметричној интеракцији показала значајно напредовање. На основу добијених квантитативних података нисмо били у могућности да издвојимо једну помоћ која је највише допринела напретку, али нам је у томе помогла квалитативна анализа интеракција испитивача и деце. Као полазна основа за квалитативну анализу послужила нам је кластер анализа, којом су издвојене четири групе деце. Ова анализа је показала да је афективно-мотивациона помоћ била саставни део сваке успешне интеракције, с тим што су се кластери разликовали према томе коју је функцију имала афективно-мотивациона помоћ при решавању теста у асиметричној интеракцији.

Добијени резултати сугеришу да је за добијање тачније информације о когнитивним капацитетима деце Свратишта неопходно напустити оквире стандардне тестовне процедуре како би им била обезбеђена могућност за боље разумевање захтева који су пред њима, као и мотивација и подршка неопходни за постизање циља интеракције.

Къучнеречи: деца из Свратишта, Косове коцке, асиметрична интеракција, тестирање когнитивних способности, динамичко тестирање. 